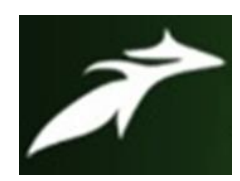

Hariom Kumar Yadav et al, International Journal of Advances in Agricultural Science and Technology, Vol.8 Issue.1, January-2021, pg. 132-138

ISSN: 2348-1358

Impact Factor: 6.057

NAAS Rating: 3.77

\title{
A STUDY ON ADOPTION BEHAVIOUR OF WHEAT GROWERS IN IMPROVED PRODUCTION PRACTICES IN WADRAFNAGAR BLOCK OF BALRAMPUR DISTRICT OF CHHATTISGARH
}

\author{
Hariom Kumar Yadav*; Dr. Dipak Kumar Bose \\ Department of Agricultural Extension and Communication \\ Sam Higginbottom University of Agriculture, Technology \& Sciences, Prayagraj, 211007 (U.P.) India \\ Research Scholar*E-mail: hariomyadavji052@gmail.com \\ Professor** E-mail: dipak.bose@ shiats.edu.in \\ DOI: 10.47856/ijaast.2021.v08i1.017
}

\begin{abstract}
The present study was conducted in the Balrampur district of Chhattisgarh. 120 respondent were selected from 10 village of Wadrafnagar block. The data was elicited through personal interview method. From the study it was found that majority $58.33 \%$ of the respondents fell in the medium adoption level group, whereas 30.00 per cent respondents were observed in the high adoption level group and remaining 11.66 per cent respondents were low adoption level group. Independent variables, namely education, annual income, land holding, extension contact and social participation had positive and significant relationship with adoption while age, family size and family type shows non significant relationship with adoption of improved cultivation practices of wheat growers
\end{abstract}

Keywords: Wheat, Balrampur, Chhattisgarh.

\section{INTRODUCTION}

Agriculture research and Extension are two important factors of agricultural development. During the past independence period, considerable efforts have been made in the country resulting in appreciable increase in agriculture production. There is a need for change in our approach in identifying research priorities. Indian farmers are in general resource poor and there is a greater need for research on resource assessment and management. The name wheat is given to a number of species within the genus Triticum (family Poaceae Syn. Gramineae). Triticum aestivum is presently grown in India in almost all the wheat growing zones. This wheat is introduced in India by Borlaug of Mexico and wheat is frequently said to be the Maxican dwarf wheat. (Wadge,2017) 


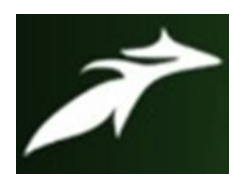

Hariom Kumar Yadav et al, International Journal of Advances in Agricultural Science and Technology, Vol.8 Issue.1, January-2021, pg. 132-138

ISSN: 2348-1358

Impact Factor: 6.057

NAAS Rating: 3.77

Wheat takes second place to maize on a worldwide basis as feed grain for livestock. However, wheat grain can equal maize in energy value and often better than maize with respect to protein concentration. Wheat compares well with other important cereals in its nutritive value. It contains more protein than other cereals. Besides, its significance in characteristics substance "gluten" which is very essential for bakers. Wheat is commonly called as "king of cereals". Wheat crop has wide adoptability. It can be grown not only in the tropical and subtropical zones but also in the cold tracts of the far north, beyond even the 600north latitude. Wheat can tolerate server cold and snow and resume growth with the setting in of warm weather in spring. It can be cultivated from sea level to as high as 3300 metres.

The present investigation is the therefore, planned to study existing adoption level of farmers about improved wheat cultivation technology.

\section{MATERIALS AND METHODS}

The present study was conducted in the Balrampur district of Chhattisgarh. Balrampur District is a part of Ambikapur (Surguja) division. There six blocks in Balrampur district. Out of which Wadrafnagar block was selected purposively for the study because of the largest cultivated area under wheat crop as compared to other blocks of the district. A complete list of all the major wheat growing villages was prepared in consultation with the personnel of revenue and agriculture department from the identified tehsils. The list so prepared, 10 villages from Wadrafnagar block was selected on the basis of maximum area under wheat cultivation. Thus, total 120 respondants were selected for the present investigation. For selection of respondents, a comprehensive list of small, marginal and large farmers of wheat growers was prepared with the help of village Patwari and agricultural supervisor of respective village. Total 120 wheat growers were included in the sample of study. 


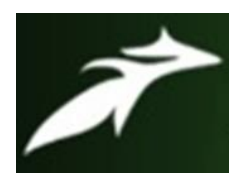

Hariom Kumar Yadav et al, International Journal of Advances in Agricultural Science and Technology, Vol.8 Issue.1, January-2021, pg. 132-138

ISSN: 2348-1358

Impact Factor: 6.057

NAAS Rating: 3.77

\section{RESULTS AND DISCUSSION}

Table 1: Distribution of wheat growers according to personal, socio-economic, and communicational characteristics

\begin{tabular}{|c|c|c|}
\hline Characteristics & Frequency $(\mathrm{N}=120)$ & Percentage \\
\hline \multicolumn{3}{|l|}{ Age group } \\
\hline Below 35 years & 28 & 23.33 \\
\hline 36 to 55 years & 68 & 56.67 \\
\hline Above 55 years & 24 & 20.00 \\
\hline Total & 120 & 100.00 \\
\hline \multicolumn{3}{|l|}{ Educational group } \\
\hline Illiterate & 34 & 28.33 \\
\hline Primary school & 42 & 35.00 \\
\hline High School & 18 & 15.00 \\
\hline Intermediate & 16 & 13.33 \\
\hline Graduate and Above & 10 & 08.34 \\
\hline Total & 120 & 100.00 \\
\hline \multicolumn{3}{|l|}{ Size of land holding } \\
\hline Less than 1 hectares & 40 & 33.33 \\
\hline 1 to 2 hectares & 48 & 40.00 \\
\hline More than 2 hectares & 32 & 26.67 \\
\hline Total & 120 & 100.00 \\
\hline \multicolumn{3}{|l|}{ Annual income of respondent } \\
\hline Below Rs. 50, 000 & 40 & 33.33 \\
\hline Rs. 50,001 to $1,00,000$ & 48 & 40.00 \\
\hline Above Rs. 1,00,000 & 32 & 26.67 \\
\hline Total & 120 & 100.00 \\
\hline
\end{tabular}




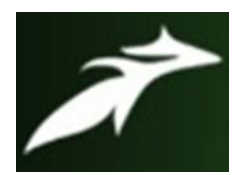

Hariom Kumar Yadav et al, International Journal of Advances in Agricultural Science and Technology, Vol.8 Issue.1, January-2021, pg. 132-138

ISSN: 2348-1358

Impact Factor: 6.057

NAAS Rating: 3.77

\begin{tabular}{|c|c|c|}
\hline \multicolumn{3}{|l|}{ Family size } \\
\hline Small size (up to 5 members) & 43 & 35.83 \\
\hline $\begin{array}{r}\text { Large size (above } 5 \\
\text { members) }\end{array}$ & 77 & 64.16 \\
\hline Total & 120 & 100.00 \\
\hline \multicolumn{3}{|l|}{ Family Type } \\
\hline Nuclear families & 76 & 63.33 \\
\hline Joint families & 44 & 36.67 \\
\hline Total & 120 & 100.00 \\
\hline \multicolumn{3}{|l|}{ Extension Contact } \\
\hline Low & 22 & 18.33 \\
\hline Medium & 62 & 51.67 \\
\hline High & 36 & 30.00 \\
\hline Total & 120 & 100.00 \\
\hline \multicolumn{3}{|l|}{ Social Participation } \\
\hline Low & 25 & 20.83 \\
\hline Medium & 68 & 56.66 \\
\hline High & 27 & 22.50 \\
\hline Total & 120 & 100.00 \\
\hline
\end{tabular}

Distribution of wheat growers according to personal, socio-economic, and communicational characteristics

Majority of respondents belonged to the age group of 36 to 55 years. This group alone constitutes 56.67 per cent of the total sample. Majority of respondents belonged to the primary school education $(35.00 \%)$ and about 40.00 percent respondents have 1 to 2 ha. land. Maximum percentage of the respondents $(40.00 \%)$ were found in annual income range of Rs. 50001 to 100000 . majority of respondents i.e. 64.16 per cent were from large families and 63.33 per cent families were nuclear in their compassion. Majority of respondents $(51.67 \%)$ have medium extension contact and $56.66 \%$ respondents have medium social precipitation.

Adoption level of wheat growers about their improved cultivation practices.

The adoption level of the wheat growers about their improved cultivation practices was measured with the help of adoption test development for the study. The respondents were categorized into three groups based on equal interval method as presented in Table 2. 


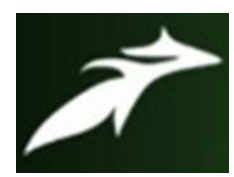

Hariom Kumar Yadav et al, International Journal of Advances in Agricultural Science and Technology, Vol.8 Issue.1, January-2021, pg. 132-138

ISSN: 2348-1358

Impact Factor: 6.057

NAAS Rating: 3.77

Table 2: Adoption of wheat production practices by the respondents

\begin{tabular}{|c|c|c|c|c|}
\hline \multirow[t]{2}{*}{ S. No. } & \multirow[t]{2}{*}{ Aspects/ Practices } & \multicolumn{3}{|c|}{ Adoption Level } \\
\hline & & $\begin{array}{c}\text { Fully } \\
\text { Adopted } \\
\text { F (\%) }\end{array}$ & $\begin{array}{c}\text { Partially } \\
\text { Adopted } \\
\text { F (\%) }\end{array}$ & $\begin{array}{c}\text { Not Adopted } \\
\text { F (\%) }\end{array}$ \\
\hline 1. & Use of high yielding varieties & $\begin{array}{c}30 \\
(25.00)\end{array}$ & $\begin{array}{c}70 \\
(58.33)\end{array}$ & $\begin{array}{c}20 \\
(16.66)\end{array}$ \\
\hline 2. & Soil and soil treatments & $\begin{array}{c}40 \\
(33.33)\end{array}$ & $\begin{array}{c}65 \\
(54.16)\end{array}$ & $\begin{array}{c}15 \\
(12.50)\end{array}$ \\
\hline 3. & Field preparation & $\begin{array}{c}35 \\
(29.16)\end{array}$ & $\begin{array}{c}70 \\
(58.33)\end{array}$ & $\begin{array}{c}15 \\
(12.50)\end{array}$ \\
\hline 4. & Seed rate & $\begin{array}{c}38 \\
(31.67)\end{array}$ & $\begin{array}{c}62 \\
(51.66)\end{array}$ & $\begin{array}{c}20 \\
(16.67)\end{array}$ \\
\hline 5. & Recommended spacing \& & $\begin{array}{c}55 \\
(45.83)\end{array}$ & $\begin{array}{c}50 \\
(41.66)\end{array}$ & $\begin{array}{c}15 \\
(12.50)\end{array}$ \\
\hline 6 & depth & $\begin{array}{c}30 \\
(25.00)\end{array}$ & $\begin{array}{c}60 \\
(50.00)\end{array}$ & $\begin{array}{c}30 \\
(25.00)\end{array}$ \\
\hline 7. & Seed treatments & $\begin{array}{c}30 \\
(25.00)\end{array}$ & $\begin{array}{c}65 \\
(54.16)\end{array}$ & $\begin{array}{c}25 \\
(20.84)\end{array}$ \\
\hline 8. & Time \& method of sowing & $\begin{array}{c}40 \\
(33.33)\end{array}$ & $\begin{array}{c}60 \\
(50.00)\end{array}$ & $\begin{array}{c}20 \\
(16.67)\end{array}$ \\
\hline 9. & Fertilizers application & $\begin{array}{c}27 \\
(22.50)\end{array}$ & $\begin{array}{c}63 \\
(52.50)\end{array}$ & $\begin{array}{c}30 \\
(25.00)\end{array}$ \\
\hline 10. & Use of micronutrients & $\begin{array}{c}32 \\
(26.66)\end{array}$ & $\begin{array}{c}688 \\
(56.66)\end{array}$ & $\begin{array}{c}20 \\
(16.67)\end{array}$ \\
\hline 11. & Weed managements & $\begin{array}{c}45 \\
(37.50)\end{array}$ & $\begin{array}{c}60 \\
(50.00)\end{array}$ & $\begin{array}{c}15 \\
(12.50)\end{array}$ \\
\hline 12. & Irrigation managements & $\begin{array}{c}51 \\
(42.50)\end{array}$ & $\begin{array}{c}45 \\
(37.50)\end{array}$ & $\begin{array}{c}24 \\
(20.00)\end{array}$ \\
\hline 13. & Plant protection measures & $\begin{array}{c}47 \\
(39.16)\end{array}$ & $\begin{array}{c}44 \\
(36.66)\end{array}$ & $\begin{array}{c}29 \\
(24.16)\end{array}$ \\
\hline
\end{tabular}




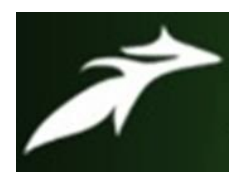

Hariom Kumar Yadav et al, International Journal of Advances in Agricultural Science and Technology, Vol.8 Issue.1, January-2021, pg. 132-138

ISSN: 2348-1358

Impact Factor: 6.057

NAAS Rating: 3.77

Table 3: Distribution of respondents according to their overall adoption level about improved cultivation practices of wheat

\begin{tabular}{|c|c|c|c|}
\hline $\begin{array}{c}\text { Adoption } \\
\text { level }\end{array}$ & Knowledge & Frequency & Percentage \\
\hline Low & $(12$ to 15$)$ & 14 & 11.66 \\
\hline Medium & (16 to 19$)$ & 70 & 58.33 \\
\hline High & (Above 19$)$ & 36 & 30.00 \\
\hline Total & & $\mathbf{1 2 0}$ & $\mathbf{1 0 0 . 0 0}$ \\
\hline
\end{tabular}

Table 3 revealed that majority of the respondents $70(58.33 \%)$ fell in the medium adoption level group, whereas 30.00 per cent respondents were observed in the high adoption level group and remaining 11.66 per cent respondents formed low adoption level group. It is hereby concluded that majority of farmers were having medium level of adoption followed by high and low adoption level, respectively.

Table 4: Relationship between selected variables of wheat growers and their level of adoption of recommended package of practices

\begin{tabular}{|c|l|c|}
\hline S. No. & \multicolumn{1}{|c|}{ Independent variables } & $\begin{array}{c}\text { Correlation coefficient } \\
(\mathbf{r})\end{array}$ \\
\hline $\mathbf{1 .}$ & Age & $-0.086 \mathrm{NS}$ \\
\hline $\mathbf{2 .}$ & Education & $0.042^{* *}$ \\
\hline $\mathbf{3 .}$ & Annual income & $0.248^{* *}$ \\
\hline $\mathbf{4 .}$ & Land holding & $0.514^{* *}$ \\
\hline $\mathbf{5 .}$ & Family size & $0.125 \mathrm{NS}$ \\
\hline $\mathbf{6 .}$ & Family type & $0.012 \mathrm{NS}$ \\
\hline $\mathbf{7 .}$ & Extension contact & $0.235^{* *}$ \\
\hline $\mathbf{8 .}$ & Social participation & $0.175^{* *}$ \\
\hline
\end{tabular}

** Correlation is significant at the 0.05 level of probability NS= Non-significant

From Table 4 correlation analysis revealed that independent variables, namely education, annual income, land holding, extension contact and social participation had positive and 


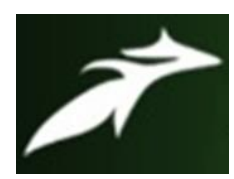

Hariom Kumar Yadav et al, International Journal of Advances in Agricultural Science and Technology, Vol.8 Issue.1, January-2021, pg. 132-138

ISSN: 2348-1358

Impact Factor: 6.057

NAAS Rating: 3.77

significant relationship with adoption while age, family size and family type shows non significant relationship with adoption of improved cultivation practices of wheat growers.

\section{CONCLUSION}

It was concluded that the socio-economic status of the respondents were medium level, practices wise adoption level of the respondents reveal that respondents had medium to high level adoption in the practices like irrigation management and filed preparation, followed by harvesting and storage, fertilizer application and seed rate. Least adoption was observed in the practices plant protection measures.

\section{REFERENCES}

[1]. Bhabhor G. K. U.M. Patel and N. D. Makwana 2017. Factors affecting the technological gap of tribal wheat growers. KVK, AAU, Dahod Gujarat.

[2]. Jakkawad S. D. Patange N. R. Kadam S. B. 2019. Extent of adoption of practices by cotton growers J. Trends in Bioscience 12(3).

[3]. Patel, M.M., Chatterjee, Amit and Khan, Mohmood, 2003, Adoption of wheat production technology. Indian Journal of Extension Education, XXXIX (1\&2): 58-62.

[4]. Patodiya, R. S. (2018). Knowledge and adoption of scientific wheat cultivation practices in Rajasthan. Indian Research Journal of Extension Education. 18(1):93-95.

[5]. Singh, K. and Singh P. (2000). "Farmers knowledge of wheat production technology in Eastern Rajasthan.” Raj. J. Extn. Edu, 8 \& 9 : 71-74.

[6]. Wadge, S. K. (2017). Knowledge and adoption of kharif maize production technology among the growers. Doctoral dissertation, Vasantrao Naik Marathwada Krishi Vidyapeeth, Parbhani. 